\title{
ENVIRONMENTAL AND GENETIC EVALUATION IN 46,XY DISORDERS OF SEX DEVELOPMENT
}

\author{
Shereen A. Abdelkader (1); Moustafa H. Ragab (2); Hala Awadallah ${ }^{(2)}$; \\ Alaa Kh. Kamel ${ }^{(1)}$ and Inas M. Mazen ${ }^{(3)}$ \\ 1) Department of Human Cytogenetics, National Research Centre 2) Department \\ of Environmental Medical Science, Institute of Environmental Studies and \\ Research. 3) Department of Clinical Genetics, National Research Centre.
}

\begin{abstract}
The phenotype of Disorders of Sex Development (DSD) patients depends on many factors including the presence of Copy Number Variation (CNVs) of different genes. The unbalanced rearrangement and the presence of deletions or duplications affect dramatically the phenotypic sex. The aim of this study is to correlate genotypic abnormalities with clinical phenotype in 46,XY DSD patients by Multiplex Ligation dependant Probe Amplification (MLPA) technique for accurate diagnosis in these patients and study possible paternal and maternal exposure to environmental risk factors in these cases. This study reported on forty patients with variable presentations of disorders of sex development (DSD) presenting with ambiguous genitalia, hypospadias, micropenis or with female phenotype with primary amenorrhea or short stature, with exclusion of cases with disorders in androgen synthesis. A complete personal, family history and clinical examination were done. Parents were asked to fill a questionnaire about frequency of dealing with some environmental factors including smoking, caffeine and using some materials having estrogenic effect as plastics, insecticides, and others. Conventional cytogenetics studies and fluorescence in situ hybridization (FISH) on peripheral blood as well as DNA extraction and Multiplex Ligation-dependent Probe Amplification (MLPA) were done for all cases for some genes; DMRT1, CYP17A1, SRD5A2, HSD17B3, DAX1, CXor21, SOX9, SRY, ZFY, WNT4 and SF. Results showed 46,XY was shown in all patients. MLPA analysis showed Copy Number Variation (CNVs) in $15 \%$ of cases. The study showed duplication of DMRT1 in 5\% patients, deletion of SRY $2.5 \%$ patients, deletion of SOX9 in 5\% patients, duplication of DAX1 in $12.5 \%$ patient, duplication of CYP17A41 in 5\% patients, deletion of
\end{abstract}


DMRT1 in $12.5 \%$ patient, duplication of SRD5A in $2.5 \%$ patient and duplication of HSD17B3 in 2.5\% patient. Maternal exposure during pregnancy and paternal exposure to Endocrine Disrupting Compounds (EDCs) were insignificantly associated with DSD compared to control cases. This study demonstrates the importance of proper detection of genetic mutation in DSD patients showing a discrepancy between their karyotype and gonadal phenotype. It was concluded that using MLPA is recommended for better understanding of the phenotype with other recent techniques as for better diagnosis and follow up. Key Words: Disorders of sex Development, Multiplex Ligation Probe Amplifications, Copy Number Variations, Endocrine Disrupting Compounds.

\section{INTRODUCTION}

Sex of rearing depends on many factors; genetic sex, degree of virilization of external genitalia, prospects of restoring normal appearance of external genitalia, fertility. Genital surgery is often required; but still the type and time of surgery are debatable (Walia et al., 2018).

Disorders of sex development (DSD) are a group of heterogeneous conditions with diverse pathophysiology. They are generally characterized by an abnormality of the chromosomal, gonadal or phenotypic features that typically define sex development. Such conditions usually present with atypical genitalia in the newborn period or as delayed puberty in an adolescent or present later in life as infertility (Hughes et al., 2008).

A number of genes are contributed to both early and late sex determination and differentiation. NR5A1, WT1, DAX1, SOX9, SRY and DMRT1 are genes required for the formation of the bipotential gonadal ridge (Wilhelm et al.; 2007). DMRT1 is suggested to have an important role in sex differentiation. Some DSD cases are due to haploinsufficiency of DMRT1 gene located on chromosome 9 (Marsudi et al., 2018). Also 5-alpha-reductase is involved in 
male sexual development by converting testosterone to DHT in males. Previous studies reported that SRD5A2 gene mutations is behind 46,XY DSDs in some cases (Fu et al., 2016).

Classification of disorders of sexual development (DSD) was modified to include three broad groups: sex chromosome DSD, 46,XX DSD, and 46,XY DSD.46,XY DSD has three broad categories; Disorders of gonadal development, Disorders in androgen synthesis or action and other causes as hypogonadotropic hypogonadism, cryptorchidism, and isolated hypospadius (Hughes et al.; 2006). 46,XY DSD is the commonest of DSD cases (65.9\%) (Mazen \& Ismail, 2010).

Several environmental pollutants, including organoclorine pesticides, polychlorinated biphenyls, bisphenol A, phthalates, dioxins and furans have estrogenic and anti androgenic activity and are thus considered as EDCs. Male sex differentiation is critically dependant on the normal production and action of androgen during fetal life. So EDCs may alter normal sex differentiation (Gaspari et al.; 2011). A study suggested that paternal environmental exposures may increase the risk of genital abnormality in newborn boys, which may indicate an effect on the paternal germline. Genital ambiguity was associated with paternal exposure to pesticides, and was found more frequent in fathers who were active smokers (Pierik et al., 2004). Fetal exposure to endocrine disruptors with estrogen-like or antiandrogen-like activity through their mothers has been suggested as a cause for testicular dysgenesis (Sharpe, 2012).

Genetic testing is recognized as a key element in the investigation of individuals with a suspected DSD. The first line investigation of a possible DSD includes karyotype and FISH analysis, which is crucial when there is uncertainty 
about sex assignment but also is an important guide for management (Schober et al.; 2012).

This study aimed at clarifying the possible paternal and maternal environmental risk factors leading to $46, \mathrm{XY}$ DSD and correlating genetic abnormalities detected with the clinical features of 46,XY DSD.

\section{SUBJECTS AND METHODS}

The study was carried out on selected forty cases of 46,XY DSD patients from cases referred from the Endocrinology Clinical Genetics Department, Centre of Excellence, National Research Centre (NRC) to the Human Cytogenetics Department. Selected cases included patients presenting with ambiguous genitalia, hypospadias, infertility, and micropenis or female phenotype with short stature or primary amenorrhea with exclusion of cases with disorders in androgen synthesis. Age ranges from birth to adulthood. Patient's mothers were subjected to a questionnaire, previously was used in a European community study, but modified; for residence, occupation, supplements, drugs, exposure to some products with EDCs. Fathers will be subjected to questionnaire on lifestyle, occupation and exposures to EDCs commonly used in daily living according to USEPA (United States Environmental Protection Agency) (Gaspari et al., 2011).

Parents of forty normal individuals with age matching the patients were included in the study as control group. Control group was approached consecutively and an informed consent was obtained from patients/control group or legal guardians. 
Patients were subjected to clinical evaluation for disorders of sex development, which is done by the clinical team was included; Full history and pedigree analysis. Thorough clinical examination with special emphasis on the phenotypic description of external genitalia was classified according to Quigley et al., (1995). Pelvic ultrasonography was done for evaluation of internal genitalia. Hormonal studies in the form of serum Testosterone, delta 4 androstenedione DHT, both basal and after HCG stimulation as well as basal serum FSH and LH. Psychological Assessment of masculinity | feminity index was also done. Histopathology evaluation was when indicated for proper diagnosis. Conventional cytogenetics analysis was carried out on peripheral blood lymphocytes, using GTG banding technique according to Verma and Babu. (1995). DNA was extracted from $5 \mathrm{ml}$ venous blood and Multiplex Ligation-dependent Probe Amplification (MLPA) was done for all patients also FISH technique was done for some cases. Data analysis was done using the statistical package for social sciences (SPSS) version 23. Chi square tests were used for evaluation of data; statistical significance was set at 0.5 .

Challenges faced during conducting the research were in the selection of the samples to be included in the study. Forty cases were selected from hundreds of patients suffering from 46,XY DSD attending the Endocrinology Clinical Genetics Department, Centre of Excellence, National Research Centre (NRC).

\section{RESULTS}

The study included 40 patients. Positive parental consanguinity was present in $57.5 \%$. According to sex of rearing, $70 \%$ were reared as males and $30 \%$ were reared as females. Patients presented with ambiguous genitalia were 52.5\%, 
$20 \%$ with hypospadias, $17.5 \%$ with primary amenorrhea, 5\% with infertility, $2.5 \%$ with inguinal hernia and $2.5 \%$ with short stature. Cytogenetic analysis using conventional GTG banding technique was done on peripheral blood lymphocytes for all patients. 46, XY was shown in all patients. MLPA analysis was conducted on 40 patients. The results of the current study showed $15 \%$ with clinical CNVs. Duplication of DMRT1 was detected in 5\% patients, deletion in SRY was detected in $2.5 \%$ patients, and deletion in SOX9 was detected in 5\% patients, duplication in CYP17A41 in 5\% patients, deletion in DMRT1 in 2.5\% patient, duplication in SRD5A in 2.5\% patient and duplication in HSD17B3 in $2.5 \%$ patient. Data are summarized in table (1).

Table (1): Summary of reported findings in the study:

\begin{tabular}{|c|c|c|c|c|c|c|}
\hline Case & age & $\begin{array}{c}\text { Sex of } \\
\text { rearing }\end{array}$ & presentation & $\begin{array}{l}\text { External } \\
\text { genitalia }\end{array}$ & karyotype & MLPA \\
\hline 1 & $\begin{array}{r}1 \\
\text { month }\end{array}$ & Male & $\begin{array}{l}\text { Ambiguous } \\
\text { genitalia }\end{array}$ & $\begin{array}{l}\text { Ambiguos } \\
\text { genitalia Q:3 }\end{array}$ & $46, X Y$ & $\begin{array}{l}\text { dupDMRT1, } \\
\text { dup CYP17A1, } \\
\text { dup SRD5A2 }\end{array}$ \\
\hline 2 & $\begin{array}{c}4 \\
\text { years }\end{array}$ & Male & $\begin{array}{c}\text { ambiguous } \\
\text { genitalia }\end{array}$ & $\begin{array}{c}\text { left undescended } \\
\text { testis Q: } 2\end{array}$ & $46, X Y$ & del SOX9 \\
\hline 3 & $\begin{array}{c}3 \\
\text { years }\end{array}$ & Male & $\begin{array}{l}\text { ambiguous } \\
\text { genitalia }\end{array}$ & $\begin{array}{c}\text { bilateral } \\
\text { undescended } \\
\text { testis Q:4 }\end{array}$ & $46, X Y$ & del SOX9 \\
\hline 4 & $\begin{array}{c}16 \\
\text { years }\end{array}$ & female & short stature & $\begin{array}{c}\text { normal female } \\
\text { external } \\
\text { genitalaia.Q:6 }\end{array}$ & $46, X Y$ & del Sry \\
\hline 5 & 1 year & Male & $\begin{array}{l}\text { ambiguous } \\
\text { genitalia }\end{array}$ & $\begin{array}{c}\text { bilateral } \\
\text { undescended } \\
\text { testis Q: } 4\end{array}$ & $46, X Y$ & del DMRT \\
\hline 6 & $\begin{array}{c}15 \\
\text { years }\end{array}$ & Male & $\begin{array}{l}\text { ambiguous } \\
\text { genitalia }\end{array}$ & $\begin{array}{c}\text { Bilateral } \\
\text { undescended } \\
\text { testis, } \\
\text { hypospadius Q:3 }\end{array}$ & $46, X Y$ & $\begin{array}{l}\text { dupDMRT1, } \\
\text { dup CYP17A41, } \\
\text { dup HSD17B3 }\end{array}$ \\
\hline
\end{tabular}

*Q: Quigley score. 
J. Environ. Sci.

Institute of Environmental Studies and Research - Ain Shams University

Table (2): Frequent distribution of results of MLPA in the study

\begin{tabular}{|c|c|c|}
\hline MLPA results & Number & Percentage \\
\hline del SRY & 1 & $2.5 \%$ \\
\hline del DMRT & 1 & $2.5 \%$ \\
\hline dupDMRT1 & 2 & $5 \%$ \\
\hline dup CYP17A41 & 2 & $5 \%$ \\
\hline dup HSD17B3 & 1 & $2.5 \%$ \\
\hline del SOX9 & 2 & $5 \%$ \\
\hline dup SRD5A2 & 1 & $2.5 \%$ \\
\hline
\end{tabular}

Table (3): Characteristic features of the studied patients

\begin{tabular}{|l|c|c|c|}
\hline \multirow{2}{*}{ Features } & \multicolumn{2}{c|}{ Cases } \\
\cline { 2 - 4 } & Male & Count & $\%$ \\
\hline \multirow{3}{*}{ Sex } & Female & 29 & $70 \%$ \\
\cline { 2 - 4 } & Positive & 11 & $30 \%$ \\
\hline \multirow{4}{*}{ presentation } & Negative & 23 & $57.5 \%$ \\
\cline { 2 - 4 } & Ambiguous genitalia & 21 & $42.5 \%$ \\
\cline { 2 - 4 } & Hypospadias & 8 & $52.5 \%$ \\
\cline { 2 - 4 } & Primary amenorrhea & 7 & $20 \%$ \\
\cline { 2 - 4 } & infertility & 2 & $17.5 \%$ \\
\cline { 2 - 4 } & Short stature & 1 & $5 \%$ \\
\cline { 2 - 4 } & Inguinal hernia & 1 & $2.5 \%$ \\
\hline \multirow{4}{*}{$\begin{array}{l}\text { Copy number } \\
\text { variation }\end{array}$} & Detected & 6 & $15 \%$ \\
\cline { 2 - 4 } & not detected & 34 & $85 \%$ \\
\hline \hline
\end{tabular}

This study has evaluated the frequency of exposure to certain environmental materials; pesticides, soda cans, canned food, plastic cups and smoking, to the parents of patients compared to parents of normal patients (control group). There was no significant association with exposure to some environmental materials to the parents of DSD patients. The data is summarized in table (2) and (3) for comparison Chi square was used. 
Table (4): Frequency of dealing of fathers with some sources of EDCs:

\begin{tabular}{|c|c|c|c|c|c|c|}
\hline \multicolumn{2}{|l|}{ Fathers } & \multicolumn{2}{|c|}{ Cases } & \multicolumn{2}{|c|}{ Controls } & \multirow{2}{*}{$\begin{array}{c}p \\
\text { value }\end{array}$} \\
\hline & & No & $\%$ & No & $\%$ & \\
\hline \multirow{3}{*}{ Smoking } & Daily & 23 & 59.0 & 22 & 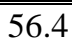 & \multirow[t]{3}{*}{0.971} \\
\hline & Never & 3 & 7.7 & 3 & 7.7 & \\
\hline & Occasionally & 13 & 33.3 & 14 & 35.9 & \\
\hline \multirow{2}{*}{ Plastic Cups } & Daily & 27 & 69.2 & 28 & 71.8 & \multirow[t]{2}{*}{0.804} \\
\hline & Occasionally & 12 & 30.8 & 11 & 28.2 & \\
\hline \multirow{2}{*}{ Plastic Bottles } & Daily & 32 & 82.1 & 32 & 82.1 & \multirow[t]{2}{*}{1.000} \\
\hline & Occasionally & 7 & 17.9 & 7 & 17.9 & \\
\hline \multirow{2}{*}{ Plastic Bag } & Daily & 32 & 82.1 & 33 & 84.6 & \multirow[t]{2}{*}{0.761} \\
\hline & Occasionally & 7 & 17.9 & 6 & 15.4 & \\
\hline \multirow{2}{*}{ Vegetarian Food } & Daily & 17 & 43.6 & 15 & 38.5 & \multirow[t]{2}{*}{0.645} \\
\hline & Occasionally & 22 & 56.4 & 24 & 61.5 & \\
\hline \multirow{2}{*}{ Insecticide } & Daily & 9 & 23.1 & 9 & 23.1 & \multirow[t]{2}{*}{1.000} \\
\hline & Occasionally & 30 & 76.9 & 30 & 76.9 & \\
\hline \multirow{2}{*}{ Soda Can } & Daily & 23 & 59.0 & 24 & 61.5 & \multirow[t]{2}{*}{0.817} \\
\hline & Occasionally & 16 & 41.0 & 15 & 38.5 & \\
\hline \multirow{3}{*}{ Food Can } & Daily & 8 & 20.5 & 8 & 20.5 & \multirow[t]{3}{*}{0.923} \\
\hline & Never & 3 & 7.7 & 4 & 10.3 & \\
\hline & Occasionally & 28 & 71.8 & 27 & 69.2 & \\
\hline \multirow{3}{*}{ Detergent and cleaning agents } & Daily & 8 & 20.5 & 7 & 17.9 & \multirow[t]{3}{*}{0.955} \\
\hline & Never & 12 & 30.8 & 12 & 30.8 & \\
\hline & Occasionally & 19 & 48.7 & 20 & 51.3 & \\
\hline
\end{tabular}

$\mathrm{P} \leq 0.05$ is considered statistically significant, analysis done by chi square test. 
J. Environ. Sci.

Institute of Environmental Studies and Research - Ain Shams University

Table (5): Frequency of dealing of mothers with some sources of EDCs:

\begin{tabular}{|c|c|c|c|c|c|c|}
\hline \multirow{2}{*}{\multicolumn{2}{|c|}{ Mothers }} & \multicolumn{2}{|c|}{ Cases } & \multicolumn{2}{|c|}{ Controls } & \multirow{2}{*}{$\begin{array}{c}\mathbf{p} \\
\text { value }\end{array}$} \\
\hline & & \multirow{2}{*}{$\begin{array}{c}\text { No } \\
1\end{array}$} & \multirow{2}{*}{$\begin{array}{c}\% \\
2.6\end{array}$} & \multirow{2}{*}{$\begin{array}{c}\text { No } \\
1\end{array}$} & \multirow{2}{*}{$\begin{array}{c}\% \\
2.6\end{array}$} & \\
\hline \multirow{3}{*}{ Smoking During Pregnancy } & Daily & & & & & \multirow{3}{*}{$1.000^{\circ}$} \\
\hline & Never & 34 & 87.2 & 35 & 89.7 & \\
\hline & Occasionally & 4 & 10.3 & 3 & 7.7 & \\
\hline \multirow{2}{*}{ Plastic Cups } & Daily & 25 & 64.1 & 25 & 64.1 & \multirow{2}{*}{1.000} \\
\hline & Occasionally & 14 & 35.9 & 14 & 35.9 & \\
\hline \multirow{2}{*}{ Plastic Bottles } & Daily & 35 & 89.7 & 34 & 87.2 & \multirow{2}{*}{$1.000^{\mathrm{a}}$} \\
\hline & Occasionally & 4 & 10.3 & 5 & 12.8 & \\
\hline \multirow{2}{*}{ Plastic Bag } & Daily & 25 & 64.1 & 24 & 61.5 & \multirow{2}{*}{0.815} \\
\hline & Occasionally & 14 & 35.9 & 15 & 38.5 & \\
\hline \multirow{2}{*}{ Vegetarian Food } & Daily & 17 & 43.6 & 16 & 41.0 & \multirow{2}{*}{0.819} \\
\hline & Occasionally & 22 & 56.4 & 23 & 59.0 & \\
\hline \multirow{2}{*}{ Insecticide } & Daily & 9 & 23.1 & 9 & 23.1 & \multirow{2}{*}{1.000} \\
\hline & Occasionally & 30 & 76.9 & 30 & 76.9 & \\
\hline \multirow{3}{*}{ Drugs \& Supplements } & Daily & 20 & 51.3 & 22 & 56.4 & \multirow{3}{*}{0.892} \\
\hline & Never & 3 & 7.7 & 3 & 7.7 & \\
\hline & Occasionally & 16 & 41.0 & 14 & 35.9 & \\
\hline \multirow{3}{*}{ Soda Can } & Daily & 16 & 41.0 & 16 & 41.0 & \multirow{3}{*}{0.894} \\
\hline & Never & 3 & 7.7 & 2 & 5.1 & \\
\hline & Occasionally & 20 & 51.3 & 21 & 53.8 & \\
\hline \multirow{3}{*}{ Food Can } & Daily & 9 & 23.1 & 11 & 28.2 & \multirow{3}{*}{0.741} \\
\hline & Never & 6 & 15.4 & 4 & 10.3 & \\
\hline & Occasionally & 24 & 61.5 & 24 & 61.5 & \\
\hline \multirow{2}{*}{ Detergent and cleaning agents } & Daily & 26 & 66.7 & 26 & 66.7 & \multirow{2}{*}{1.000} \\
\hline & Occasionally & 13 & 33.3 & 13 & 33.3 & \\
\hline \multirow{3}{*}{ Cosmetics of unknown source } & Daily & 15 & 38.5 & 15 & 38.5 & \multirow{3}{*}{1.000} \\
\hline & Never & 5 & 12.8 & 5 & 12.8 & \\
\hline & Occasionally & 19 & 48.7 & 19 & 48.7 & \\
\hline
\end{tabular}

$\mathrm{P} \leq 0.05$ is considered statistically significant, analysis done by chi square test, a: analysis done by fisher exact test 


\section{DISCUSSION}

Development of male reproductive system is a complex process controlled by sophisticated networks that depends on sex-specific differentiation and endocrine function. These regulatory cascades are often illustrated by high prevalence of genitourinary defects in newly born. These urogenital anomalies are usually difficult challenges for both parents and physicians.

Dessouky et al., 2001 stated that childhood is the most common group of presentation; this is similar to our study as we reported the ages at presentation ranged between few days and 20 years with a mean of 5.5 years.

In agreement with our study that showed the main complaints at presentation were ambiguous genitalia in 25\%, short stature in $20 \%$, hypospadias in $10 \%$, primary amenorrhea in $10 \%, 5 \%$ in infertility and short stature in 30\%, also Sema et al., 2011 mentioned nearly same percentages.

This study showed $57.5 \%$ had positive consanguinity also Shawky et al., 2011 reported that consanguineous marriage was reported among 55.56\% of patients and also Mazen \& Ismail 2010 mentioned that high degree of consanguinity in DSD was also reported in Egypt 61-65\%.

Kafla et al., 2015 stated that EDCs can cause genital abnormalities as hypospadias. Since EDCs are present in variable mixtures, so their effects are time-dependent and sometimes hard to detect. Specific causes of most of genital and urinary tract defects are still unknown. Allali et al., 2011 mentioned that quantification of exposure to these EDCs is particularly difficult and the use of questionnaires may not be reliable enough which is in agreement with our results. 
The results of the current study showed $15 \%$ with clinical CNVs using MLPA, it is considered a reliable tool for diagnosis, this is in agreement with Harisson et al., 2013 who performed MLPA to screen for deletions or duplications for SOX9, NR5A1 (Sf-1), WNT4 and DAX1. Kim et al., 2015 also reported that molecular cytogenetic analyses using MLPA would be beneficial for patients with 46,XY DSD, because identification of pathogenic CNVs could help to predict the disease outcome and possible complications of patients. Furthermore, detection of disease-associated CNVs significantly improves the accuracy of genetic counseling for patients' families.

Deletion of $S R Y$ in $2.5 \%$ of patients in the study was less than results reported by Philibert et al., 2007 who emphasized on the importance of investigating the $S R Y$ gene as a first step for 46,XY DSD patients; however, only 10\%-20\% of 46,XY gonadal dysgenesis patients show SRY gene CNVs.

In this study DMRT1 deletion was found in a phenotypically male patient presenting with ambiguous genitalia unlike Eser and Ayaz 2018 who studied a case of phenotypically female with $46, \mathrm{XY}$ who showed by further genetic analysis deletion of DMRT1 genes. They stated that few cases of XY DSD caused by DMRT1 gene abnormality reported. In addition, the pathomechanism has not been fully understood that would explain DMRT1 duplication in our patients that require further study.

The current study reports that CYP17A1 gene duplication in 5\%, also Simiao et al., 2016 concluded that $17 \alpha$-hydroxylase is a rare, unusual and challenging to diagnose endocrine disorder and was the first to demonstrate that mutations in the CYP17Al gene may be used for the diagnosis in the 
17 $\alpha$-hydroxylase patient without typical clinical symptoms. Diagnosis of $17 \alpha$-hydroxylase is confirmed by CYP17A mutation analysis.

Kim et al 2015 stated that deletions involving this region of SOX9 can result in a wide spectrum of sex development in $46, X Y$ DSD, ranging from nearly normal male phenotype to nearly complete female phenotype and that comes in agreement with our findings in 5\% with del SOX9.

Disorders of gonadal differentiation is accompanied with mutation of $S R D 5 A 2$ in $2.5 \%$ of our patients who showed duplication of SRD5A2 is explained by Byers et al 2017 who reported that the severity appears to correlate with the genotype of SRD5A2 in 46, XY DSD patients.

\section{CONCLUSION AND RECOMMENDATION}

Molecular cytogenetic analysis should be included in the diagnostic workup of patients with 46,XY DSD. MLPA appear to be useful for molecular diagnosis of patients with 46,XY DSD. It is also suggested that exposure of environmental risk factor to both mother and father was found to be not associated with genital development. Environmental risk factors are difficult to assess and may require other methods with the use of questionnaires.

\section{REFERENCES}

Allali S; Muller J-B; Brauner R; Lourenço D; Boudjenah R; Karageorgou V,

Trivin C, Lottmann H, Lortat-Jacob S, Nihoul-Fékété C, De Dreuzy O, McElreavey K, Bashamboo A.,(2011): Mutation analysis of NR5A1 encoding steroidogenic factor 1 in 77 patients with 46, XY disorders of sex development (DSD) including hypospadias. PLoS One, 6:e24117. 
Marsudi A; Kartapradja H; Paramayuda C, Jose R,; Alida R. Harahap B, and Marzuki N (2018): Loss of DMRT1 gene in a Mos 45,XY,9[8]/46,XY,r(9)[29]/ 47,XY,+idicr(9)x2[1]/ 46,XYidicr (9) [1]/ 46,XY[1] female presenting with shoert stature. Mol Cytogenet;11:28.PMID: 29760778.

Buonocore, F. and Achermann, J. C. (2016): Human sex development: Targeted technologies to improve diagnosis. Genome Biology, 17( 1), 257.

Byers D; Monach H;Patricia P;Ming C;Thomas H,;Ramsdell R; Schnorvorian $\mathrm{M}$,

Mcclauey E (2017): Unexpected ethical dilemmas in sex assignment in 46,XY DSD due to 5- alpha reductase type 2 deficiency. American Journal of Medical Genetics Part C: Seminars in Medical Genetics / Volume 175 , Issue 2

Domenice S ;Arnold P;Costa F;Medonca B(2016):46,XY disorders of sex development.Clinical Endocrinology;doi:10.1111/j.1365-2265.

Eser M and Ayaz A (2018): Haploinsufficiency of the DMRT Gene Cluster in a 46,XY ovotesticular DSD of DSD. Balkan Med J;35(3):272-274.

Fu X.; Zhang W and Qu, X., (2016): Correlation of androgen receptor and SRD5A2 gene mutations with pediatric hypospadias in 46. XY DSD Children. Genet Mol Res, 15( 1), 123- 132.

Gaspari L; Paris F;Philibert M et al., (2011): “Idiopathic" partial androgen insensitivity syndrome in 28 newborn and infant males: impact of prenatal exposure to environmental endocrine disruptor chemicals. Eur J Endocrinol;165:579-87.

Harrison M; Campell M;Keays M;Granberg F;Vilanueva C; Tannin G, Zinn A, CAstrillon H, Shaw A, Stankiewicz P, Baker L(2013): Screening and Familial Characterization of copy number variation $\mathrm{s}$ in NR5A1 in 46,XY DSD and premature ocarian failure.Am J Med GenetA(10);2487-94. 
Byers H;Monach M;Patricia Y;Chen M;Inas H ;ThomS;Linda A; Rasmdell, Elizabeth McClauley;Anne Marie ;Amies,; John M ;Park, Margart P Ada, Davis Sandberg and Catherine Keegan (2017): Unexpected Ethical Dilemma is Sex Assignment in 46,XY DSD due to 5 alpha reductase deficiency. Am J Med Genet .17592):260-267.

Hughes IA; Houk C;Ahmed SF;Lee PA; et al., (2006): Lawson Wilkins Pediatric Endocrine Society/European Society for Paediatric Endocrinology Consensus Group. Consensus statement on management of intersex disorders. J Pediatr Urol.;2(3):148-162.

Hughes IA.,(2008): Disorders of sex development: a new definition and classification. Best Pract Res Clin Endocrinol Metab 22:119-34.

Kalfa N;Fukami M; Philibert P (2015): Screening of MAMLD1 mutations in 70 children with 46,XY DSD:identification and functional analysis of two new mutations. PLoS One;7(3):e32505

Kim GJ,;Sock E;Buchberger A;Just W;Denzer F; Hoepffner W, German J, Cole T, Mann J, Seguin JH, Zipf W, Costigan C, Schmiady H;Rostasy M, Kramer M; Kaltenbach S, Rosler B, Georg I, Troppmann E; Teichmann AC, Salfelder A, Widholz SA, Wieacker P, Hiort O; Camerino G; Radi O, Wegner M, Arnold HH, Scherer G, (2015): Copy number variation of two separate regulatory regions upstream of SOX9 causes isolated $46, \mathrm{XY}$ or $46, \mathrm{XX}$ disorder of sex development. J Med Genet. doi:10.1136/jmedgenet-2014-102864

Mazen IM and Ismail SI,(2010): A study of gender outcome of Egyptian patients with 46, XY disorder of sex development. Sex Dev 4(4-5):285-91.

Dessouky N: Gender Assignment for Children with Intersex Problems: An Egyptian Perspective.. Egyptian Journal of Surgery Vol.(20),No.(2), 2001

Pierik FH; Burdorf A;Deddens JA;Juttmann RE and Weber RF.,(2004): Maternal and paternal risk factors for cryptorchidism and hypospadias: a case-control study in newborn boys. Environmental Health Perspectives 112 1570-1576. (doi:10.1289/ehp.7243) 
Philibert P;Zenaty D; Lin L; Soskin S;Audran F, Leger J, Achermann JC \& Sultan C.(2007): Mutational analysis of steroidogenic factor 1 (NR5a1) in 24 boys with bilateral anorchia: a French collaborative study. Human Reproduction. 22 3255-3261.

Quigley CA; De Bellis A and Morschke KB (1995): Androgen receptor defects: historical clinical and molecular prospective. End. Rev.;16;271321.R Walia, M Singla, K Vaiphei, S Kumar, and A Bhansali,(2018):. Disorders of sex development: a study of 194 cases. Endocr Connect; 7(2): 364-371.

Sema Erdogan;Cengiz Kara; Ahmet Ucakturk and Murat Aydin (2011): Etiological Classification and Clinical Assesment of Children and Adolescents with Disorders of Sex Development. J Clin Res Pediatr Endocrinol;jun:3(2):77-83. PMID:21750636.

Sharpe RM,(2012): Sperm counts and fertility in men: a rocky roadahead.Science \& Society Series on Sex and Science. EMBO Rep ; 13:398-403.

Shawky M; Hashem NN;El-Sedfy H; Sherif Y;AbdEl Aziz, (2001):Prevalence and phenotypic expression of various genitogonadal differentiation errors among Egyptians. Egypt J Med Hum Genet ;2(1):101-11.

Schober J;Nordenstorm A;Hoebeke P; LeeP;Houk C;Loojienga L, Manzoni G, Reiner W, Woodhouse C,(2012): Disorders of sex sex development: summaries of long term outcome studies.J Pediatr Urol;8(6):61623.doi:10.1016/j.jpurol.

Tanner JM and Davies PS. (1985): Clinical longitudinal standards for height height velocity for North American children. J Pediatr; 107:317.

Verma RS and Babu A (1995): Human chromosomes: Principles and Human chromosome manual of basic techniques. Verma RS , Babu A (eds), seconed edition, MC Graw-Hill,New york,Pergamon Press.

Wilhelm D;Palmer S;koopman p;(2007):Sex determination and gonadal development in mammals.physiol rev 87:1-28. 


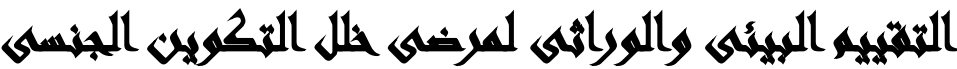

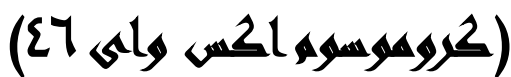

$[r]$

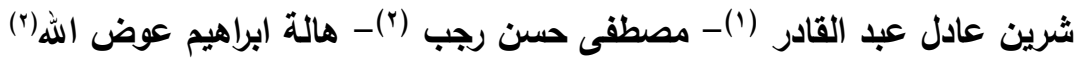

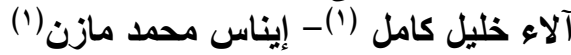

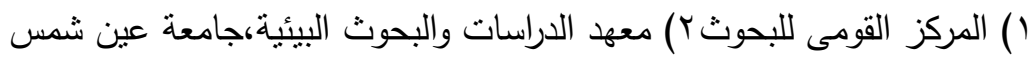

\section{المستخليس}

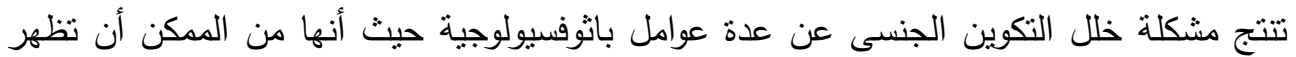

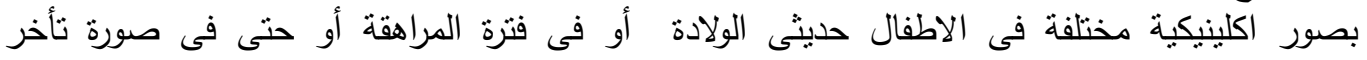

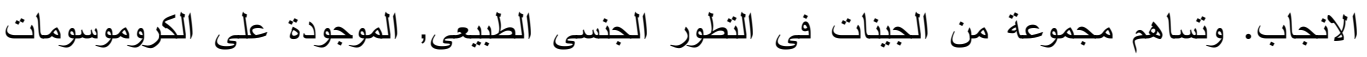

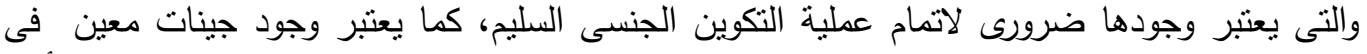

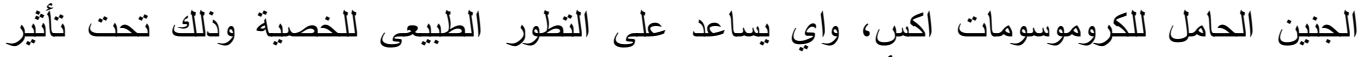

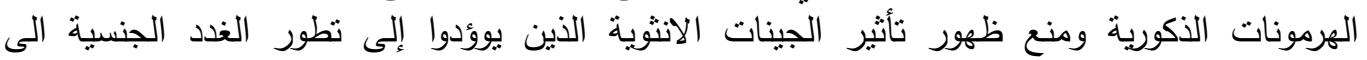

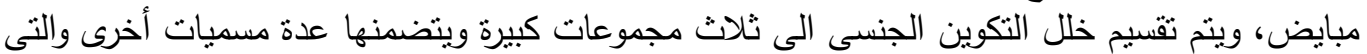

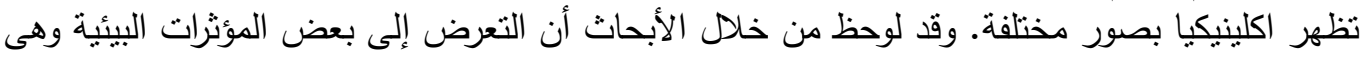

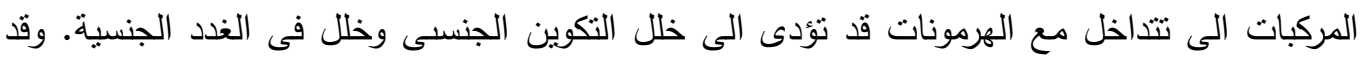

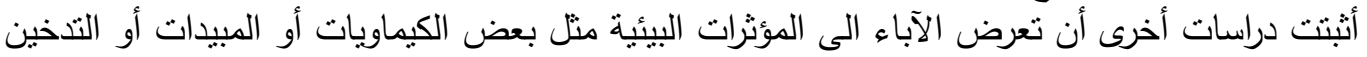

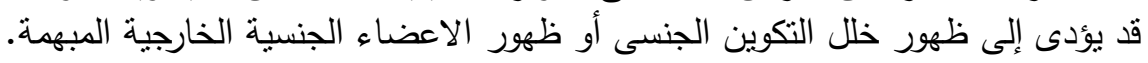

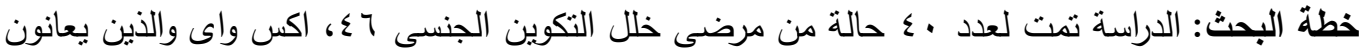

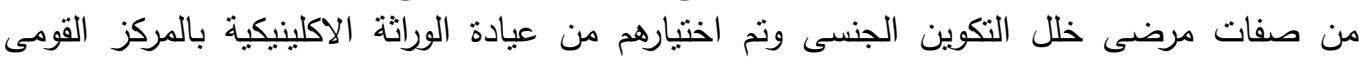

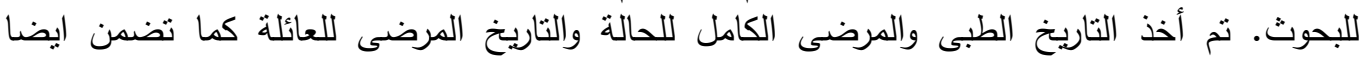

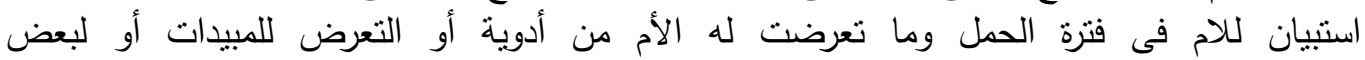

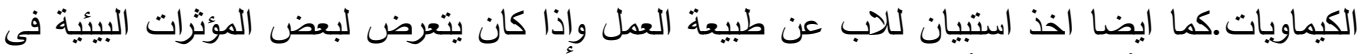

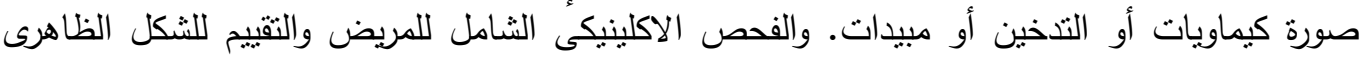

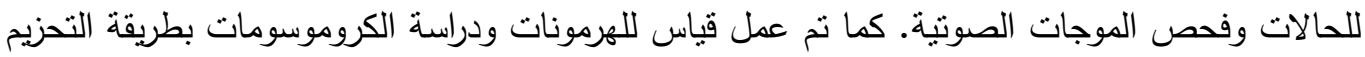

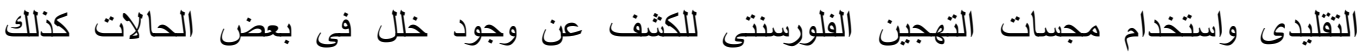

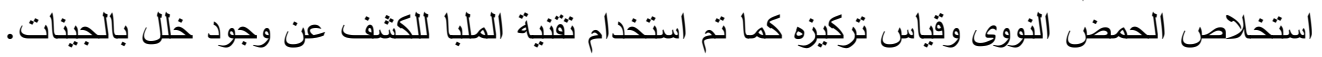

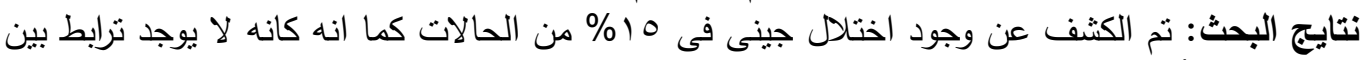

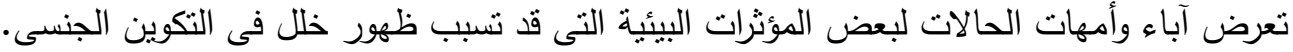

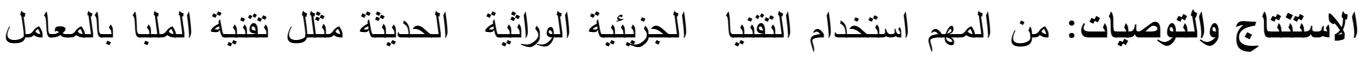
للكثف عن وجود خلل جينى فى مرضى خلل التكوين الجنسى وذللك للوصول للتشخيص السليم وللمتابعة 
J. Environ. Sci.

Institute of Environmental Studies and Research - Ain Shams University

وأيضا الفحص العائلى لبعض الحالات. كما يفضل استخدام وسائل أخرى مع الاستبيان للوصول

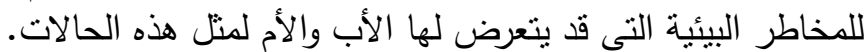

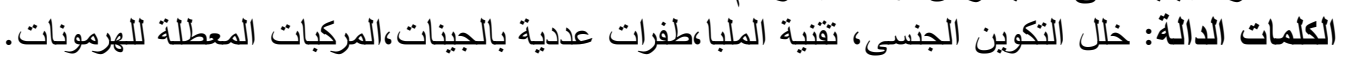

